\title{
Cytogenetics Shared Resource
}

National Cancer Institute

\section{Source}

National Cancer Institute. Cytogenetics Shared Resource. NCI Thesaurus. Code C39372.

Cytogenetics Shared Resource provides Cancer Center members with support in following areas: routine cytogenetic (such as giemsa (G)-banding on fibroblast, lymphoblast or somatic cell hybrid lines to determine karyotypes, etc.), fluorescence in situ hybridization (FISH) for clarification of karyotypes, and SKY (spectral karyotyping), to analyze chromosomal changes, microsatellite analysis of tumors for loss of heterozygosity, mutation analysis of tumors, chimerism studies of bone marrow transplants; maintenance of cell lines and lymphocytes. 